\title{
On inchoative states. Evidence from modification of Polish perfective psych verbs by degree quantifiers"
}

\author{
Ewa Willim
}

\begin{abstract}
The special properties that psych(ological) verbs manifest cross-linguistically have given rise to on-going debates in syntactic and semantic theorizing. Regarding their lexical aspect classification, while verbal psych predicates with the Experiencer argument mapped onto the subject (SE psych predicates) have generally been analyzed as stative, there is little agreement on what kinds of eventualities object Experiencer (OE) psych predicates describe. On the stative reading, OE psych predicates have been classified as atelic causative states. On the (non-agentive) eventive reading, they have been widely analyzed as telic change of state predicates and classified as achievements or as accomplishments. Based on Polish, Rozwadowska (2003, 2012) argues that nonagentive eventive OE psych predicates in the perfective aspect denote an onset of a state and that they are atelic rather than telic. This paper offers further support for the view that Polish perfective psych verbs do not denote a change of state, i.e., a transition from $\alpha$ to $\neg \alpha$. The evidence is drawn from verbal comparison and the distribution of the comparative degree quantifier jeszcze bardziej 'even more' in perfective psych predicates. It is argued here that in contexts including jeszcze bardziej 'even more', the perfective predication denotes an onset of a state whose degree of intensity exceeds the comparative standard. While a degree quantifier attached to the VP in the syntax contributes a differential measure function that returns a (vague) value representing the degree to which the intensity of the Experiencer's state exceeds the comparative standard in the event, it does not affect the event structure of the perfective verb and it does not provide the VP denotation it modifies with a final endpoint. As the perfective picks the onset of an upper open state, perfective psych predicates typically give rise to an atelic interpretation.
\end{abstract}

Keywords: psych verbs, Experiencer, inchoativity, verbal comparatives, degree quantifiers, (a)telicity

\section{$1 \quad$ Introduction}

Taken to be verbs with psychological entailments with respect to the Experiencer argument, where "[a] psychological entailment involves an individual being in a certain mental state" (Landau, 2010, p. 4), psych(ological) verbs have a number of puzzling properties crosslinguistically (see, among others, Pesetsky, 1995; Landau, 2010). ${ }^{1}$ The property that has

\footnotetext{
* This research was funded by the grant 2014/15/B/HS2/00588 from National Science Centre, Poland. Only verbs describing emotional states and events are discussed here. Other verbs of mental events: verbs of cognition and perception are not taken into consideration here, as they do not necessarily exhibit all the properties that verbs of emotion have.

${ }^{1}$ For precision, for a participant to be an Experiencer, the individual must be exercising his/her mental abilities in the situation described by a psych verb (Dowty, 1991; Jackendoff, 2009). As Dowty (1991, p. 73) explains, an Experiencer is characterized as being a sentient individual, where

[s]entience means more than a presupposition that an argument is a sentient being; it is rather sentience with respect to the event or state denoted by the verb: the objects of verbs like elect, appoint, nominate and idolize, venerate and convict, acquit, exculpate are necessarily human but are not entailed to know or perceive the relevant event.
} 
received most attention in both generative and cognitive linguistics literature is the variability of their argument realization patterns. If the two arguments of a two-place psych verb are the Experiencer and the Stimulus, respectively (see among others, Jackendoff, 2009; Croft, 2012), the variation in argument realization in the domain of psych verbs demonstrated in (1) and (2) contradicts the assumption that there is a direct and uniform association between thematic (or lexical semantic) structure and morphosyntactic expression. ${ }^{2}$ The most striking examples are pairs of near-synonymous verbs like fear and frighten, and like and appeal to (Levin and Rappaport Hovav, 2005; Levin and Grafmiller, 2013). While the Experiencer of what seems to be the same emotional state is mapped onto the subject with one of the members of the minimal pair, as in (1a) and (2a), it is mapped onto the direct (accusative) object in (1b) or onto a dative/oblique object, as in (2b), with the other member of the minimal pair. At the same time, the Stimulus is the object in (1a) and (2a), but it is the subject in (1b) and in (2b), thus challenging the linking principle:
a. Indiana Jones feared the snakes.
b. The snakes frightened Indiana Jones.
a. I like this rug.
b. This rug appeals to me.

\section{Subject Experiencer (SE)}

Object Experiencer (OE)

Subject Experiencer (SE)

Dative Object Experiencer (DE)

Differences in argument realization patterns of psych verbs further correlate with differences in the causative and aspectual readings of psych predications. While SE and DE psych predications are stative, OE predications are multiply ambiguous between stative, eventive (non-agentive) and agentive readings. According to Arad (1999), on the agentive reading illustrated in (3), the Agent acts intentionally to bring about a change of state in the Experiencer. The agentive reading is an eventive reading, as the Experiencer undergoes a change of state, but it can be distinguished from a non-agentive eventive reading illustrated in (4), in which there is no intentional Agent, but there is a change of state in the Experiencer. A stative reading, illustrated in (5), has neither an Agent nor a change of the mental state of the Experiencer. Rather, the Experiencer is in a given mental state as long as she perceives the Stimulus or it is on her mind. However, not all psych verbs can have all or some of the readings in question in a language. For example, in English the OE verbs worry and concern trigger only the stative reading, surprise receives only the eventive interpretation, while

\footnotetext{
${ }^{2}$ The assumption that there is a direct and uniform association between thematic structure and morphosyntactic expression is the answer offered in linguistic theories to the question of the nature of the relation between thematic (or lexical semantic) and syntactic structure. The traditional theoretical instruments that were introduced to explain how thematic/semantic roles are linked to syntactic positions were a universal thematic hierarchy and a linking principle, e.g., the Uniformity of Theta Assignment Hypothesis (UTAH) or the Universal Alignment Hypothesis (UAH). UTAH ensured that identical thematic relationships between items are represented by identical structural relationships between those items at the level of D-structure. The problem that the argument realization patterns of psych verbs pose for the linking principle can be resolved by taking the nonExperiencer argument to have different thematic roles in SE and OE syntax and to take SE and OE predicates to differ in their causal and aspectual structure (e.g., Pesetsky, 1995; Arad, 1999; Croft, 2012). A recent study that takes this track is Levin and Grafmiller (2013, p. 31), according to whom the emotional state of the Experiencer argument of SE predicates (fear-verbs) "should be conceptualized as a disposition directed toward something, rather than as a direct reaction to an immediate stimulus." By contrast, OE predicates (frighten-verbs) "entail certain proto-agent properties of their stimuli, most importantly, causation" (Levin and Grafmiller, 2013, p. 30). A different solution to the problem that psych verbs pose for the linking principle is to assume that the theta role of the non-Experiencer argument of both SE and OE psych verbs is the same, allow the Experiencer to be mapped above the Stimulus, and to move the Stimulus to subject position in the syntax (see Levin and Rappaport Hovav, 2005, pp. 140-145, for discussion). See also Landau (2010) and Pesetsky (1995) for syntacticallyoriented accounts of the SE/OE alternation in the domain of psychological verbs.
} 
frighten is multiply ambiguous between the stative, agentive as well as non-agentive eventive interpretations. ${ }^{3}$

Nina frightened Laura deliberately / to make her go away.
a. Nina frightened Laura unintentionally / accidentally.
b. The explosion / the noise / the thunderstorm frightened Laura.
a. This problem concerned Nina.
b. Blood sausage disgusts Nina.

To account for the interpretive differences, psych verbs have been argued to be associated with distinct event structures as well as syntactic structures (Grimshaw, 1990; Pesetsky, 1995; Arad, 1999; Rothmayr, 2009; Landau, 2010). Restricting attention to aspectual classification, on the agentive reading, psych predications have been analyzed as accomplishments denoting a process leading up to a change of state (Grimshaw, 1900; Landau, 2010). As events of change described with OE verbs like frighten (cf. (4)) are not extended in time, on their nonagentive eventive readings, OE psych verbs have been classified as (telic) achievement predicates by, among others, Pustejovsky (1991), van Voorst (1992) and Filip (1996), and as causative states by Rothmayr (2009) and Alexiadou and Iordăchioaia (2014). The stative reading of the examples in (5) identifies a causative state for Rothmayr (2009). The stative/eventive ambiguity can also be found in the domain of SE verbs in English, as originally observed by Vendler (1967, p. 112), who classified the eventuality described with know in (6) as an achievement:

\section{a. And then suddenly I knew! \\ b. Now I know it!}

To the extent that a psych predicate is an achievement, it is lexically characterized as an event of instantaneous change "from $a$ to $\neg a$ which consists of two instants, the last instant $i$ at which $a$ holds and the first instant $i$ ' at which $\neg a$ holds, where crucially there is no instant intervening between $i$ and $i$ "' (Rothstein, 2008, p. 179). Transitions from one state to another, i.e., from $\alpha$ to $\neg \alpha$, have traditionally been modeled with the BECOME operator (see, a.o., Rothstein, 2008; Marín and McNally, 2011 for recent discussion). ${ }^{4}$ Although this approach to the event structure of achievement predicates has been very influential, it has recently been challenged by Rozwadowska $(2003,2012)$ based on Polish psych verbs and by Marín and McNally (2011) with reference to Spanish reflexive psych predicates (see also Ramchand, 2004 in reference to Russian), where rather than achievements, psych verbs are argued to be initial boundary predicates denoting either an onset of a state or an onset of a state and some temporal extent of the associated state. The main aim of this paper is to show that the approach on which Polish psych predicates are analyzed as atelic initiation predicates is on the right track and that it can explain better the availability of psych verbs in the perfective form in Polish in a comparative construction like (7), a headline from a random internet search, than an approach on which psych predicates in the perfective are taken to denote

\footnotetext{
${ }^{3}$ The stative/eventive ambiguity is not peculiar to psych verbs. Other verbs that display it are verbs that have the instrument alternation like obstruct, dispositional verbs like help and perception verbs like hear. See Rothmayr (2009) for a discussion of the grammatical reflexes of the difference between the two readings, including the (un)availability of manner adverbials, event-related locative modifiers and the temporal/degree readings of the degree adverb ein bisschen 'a little' in German.

${ }^{4}$ In contrast to achievements, accomplishments denote extended events of change, i.e., $i$ and $i$ ' are not adjacent but separated by an interval (Rothstein, 2008, p. 177).
} 
eventualities in which the Experiencer undergoes a change from not being in the emotional state lexicalized by the verb to being in that state. ${ }^{5}$ Example (8), a headline from an internet article like (7), shows that the perfective pokochac' 'start to love' can also encode an onset of the emotional state that does not presuppose that the Experiencer is already in the state of love at the reference time for the event.

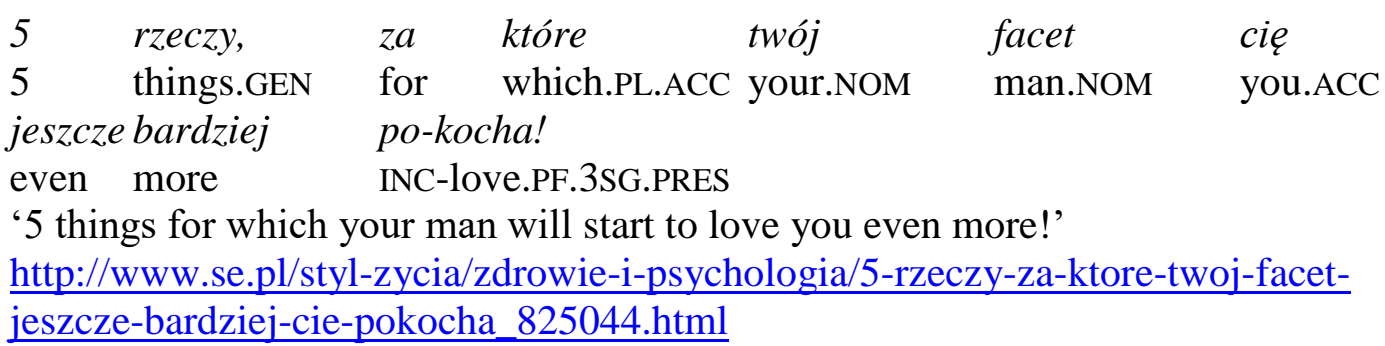

6 powodów, dla których po-kochasz
$6 \quad$ reasons.GEN for which.PL.GEN INC-love.PF.2SG.PRES cabbage.ACC
'6 reasons for which you will start to love cabbage'
http://www.nto.pl/styl-zycia/kulinaria/a/6-powodow-dla-ktorych-pokochasz-
kapuste, $10076128 /$

The syntactic context illustrated in (7) involves a comparative degree quantifier adjoined to the VP in the syntax. Although a minimal change of the degree of the intensity of an emotional state of the Experiencer can satisfy the requirements of the comparative predicate bardziej 'more', even if the interval at which a predicate like pokochać jeszcze bardziej 'start to love even more' is true must be minimal, it cannot make reference to the final instant at which the Experiencer is not in the state lexicalized by the psych verb. ${ }^{6}$ If the perfective predicate pokochać 'start to love' illustrated in (7) and (8) denoted a non-extended event of change from a state in which the Experiencer is not in love to a state in which the Experiencer is in love, the degree of the intensity of the Experiencer's emotional state could not be measured against the degree provided by the comparative standard and return a difference value, positive when exceeding the comparative standard degree and zero otherwise, as required by the comparative degree quantifier in the approach to comparatives advocated by, among others, Kennedy and McNally (2005), Kennedy (2007), and Kennedy and Levin (2008). On the other hand, if the perfective predicate pokochać 'start to love' denotes an onset of/into the state lexicalized by the verb, the Experiencer is in this state at the initial instant in an interval in which the predicate is true, making possible measurement and comparison of the degree of the intensity of the state of the Experiencer at the reference moment for the event with the degree of the same state holding at a distinct temporal moment at which that

\footnotetext{
${ }^{5}$ The abbreviations used in the remainder: IMPF - imperfective aspect, PF - perfective aspect, PRES - present tense, PAST - past tense, COND - conditional mood, IMP - imperative mood, INF - infinitive, INC - inceptive prefix, TERM - terminative prefix, DISTR - distributive, RF - reflexive, NOM - nominative, ACC - accusative, GEN - genitive, DAT - dative, INSTR - instrumental, LOC - locative, $\mathrm{M}$ - masculine gender, $\mathrm{F}$ - feminine gender, $\mathrm{N}$ neuter gender.

${ }^{6}$ While psychological phenomena raise general questions about their measurement criteria, that a comparative statement about the intensity of an emotional state is possible even when the difference in the compared values is the smallest possible value is demonstrated with the example in (i) from an internet article:
}

(i)

\begin{tabular}{|c|c|c|c|c|}
\hline $\begin{array}{l}\text {...choć mnie } \\
\text { though me.DAT }\end{array}$ & $\begin{array}{l}\text { oso } \\
\text { per }\end{array}$ & $\begin{array}{l}\min \\
\min \end{array}$ & $\begin{array}{l}\text { lnie } \\
\text { lly }\end{array}$ & $\begin{array}{l}\text { bardziej } \\
\text { more }\end{array}$ \\
\hline podobaja & sie & kolory & $z$ & aparatu. \\
\hline like.IMPF.3PL.PRES & RF & colours.NOM & from & camera.GEN \\
\hline
\end{tabular}


state is true in a distinct situation. Thus, the availability of perfective psych predicates in the comparative construction in Polish speaks against analyzing them as denoting non-extended events of change of state and against modelling that change with the BECOME operator, which picks the transition from $a$ to $\neg a$, in this case a transition from an emotional state not holding of the referent of the Experiencer argument to a state holding of the referent in the event referred to with a perfective psych predicate.

The remainder of this paper is structured as follows. In section 2, I overview the arguments advanced by Rozwadowska $(2003,2012)$ in support of analyzing perfective psych verbs in Polish as inceptive/inchoative eventualities denoting an onset of a state, which she takes to be left boundary happenings in the sense of Piñón (1997), similarly to how reflexive psych verbs in Spanish are analyzed in Marín and McNally (2011). In section 3, I provide further examples of both SE and OE perfective psych predicates modified by the comparative degree quantifier jeszcze bardziej 'even more' which demonstrate that they lack the entailment that the Experiencer is not in the emotional state lexicalized by the base verb at a temporal moment immediately prior to the salient, definite time instant that is picked by the perfective operator. This shows that perfective psych predicates do not denote non-extended events of change in which the Experiencer undergoes a change from not being in the state lexicalized by the base verb to being in that state. Rather, they only include reference to the initial interval at which the eventuality described with the perfective predicate is true. Not including reference to the final instant at which the state does not hold, they are available for verbal comparison with respect to the intensity of the emotional states of the Experiencer at distinct instants in distinct events. Section 4 concludes.

\section{Polish psych verbs}

\subsection{Basic facts and observations}

Like many other languages, including Czech, Russian, Dutch, Italian and French as well as some South Asian languages (Filip, 1996; Landau, 2010), Polish has three classes of psych verbs: SE, OE and DE, as illustrated in (9)-(11) respectively below:

$$
\begin{array}{lll}
\text { Jan } & \text { kocha } & \text { Marie. } \\
\text { John.NOM } & \text { loves } & \text { Mary.ACC } \\
\text { 'John loves } & \text { Mary.' } &
\end{array}
$$

\begin{tabular}{|c|c|c|c|}
\hline $\begin{array}{l}\text { Zdrowie } \\
\text { health.NOM }\end{array}$ & $\begin{array}{l}\text { Jana } \\
\text { John.GEN }\end{array}$ & $\begin{array}{l}\text { niepokoi } \\
\text { bothers }\end{array}$ & $\begin{array}{l}\text { Marię. } \\
\text { Mary.ACC }\end{array}$ \\
\hline
\end{tabular}

$\begin{array}{llllll}\text { Pomyst } & \text { Jana } & \text { podoba } & \text { się } & \text { Marii. } & \text { DE } \\ \text { idea.NOM } & \text { John.GEN } & \text { appeals } & \text { RF } & \text { Mary.DAT } & \\ \text { 'John's idea appeals to Mary.' } & & & \end{array}$

Other examples of SE verbs include bać się 'fear', nienawidzić 'hate', lubić 'like', podziwiać 'admire' and reflexive verbs related to OE verbs like cieszyć się 'rejoice', wściekać się 'rage, be mad'. Other examples of OE verbs: ciekawić 'interest', zniechęcać 'discourage', rozczarować 'disillusion'. DE psych verbs include przeszkadzać 'annoy' and imponować 'impress'. The aspectual contrast between simple stative eventualities and inchoative eventualities, both stative and eventive, is encoded morphologically as the contrast between 
imperfective and perfective verbs or verb forms. ${ }^{7}$ However, not all psych verbs come in pairs. Examples include bać się 'fear' and podziwiać 'admire', which are imperfectiva tantum. The infinitival variants of the verbs given above that have both forms are provided in (12):

$$
\begin{aligned}
& \text { a. } \quad \text { kochać 'love.IMPF' } \\
& \text { b. } \quad \text { niepokoić 'bother.IMPF' } \\
& \text { c. } \quad \text { podobać się 'appeal_to.IMPF' } \\
& \text { d. } \quad \text { nienawidzić 'hate.IMPF' } \\
& \text { e. } \quad \text { lubić 'like.IMPF' } \\
& \text { f. } \quad \text { cieszyć się 'rejoice.IMPF' } \\
& \text { g. } \quad \text { wściekać się 'rage.IMPF' } \\
& \text { h. } \quad \text { ciekawić 'interest.IMPF' } \\
& \text { i. } \quad \text { zniechęcać 'discourage.IMPF' } \\
& \text { j. } \quad \text { rozczarowywać 'disillusion.IMPF' } \\
& \text { k. } \quad \text { przeszkadzać 'annoy.IMPF' } \\
& \text { l. } \quad \text { imponować 'impress.IMPF' }
\end{aligned}
$$

$\begin{array}{ll}\text { pokochać 'love.PF' } & \mathrm{SE} \\ \text { zaniepokoić 'bother.PF' } & \mathrm{OE} \\ \text { spodobać się 'appeal_to.PF' } & \mathrm{DE} \\ \text { znienawidzić 'hate.PF' } & \mathrm{SE} \\ \text { polubić 'like.PF' } & \mathrm{SE} \\ \text { ucieszyć się 'rejoice.PF' } & \mathrm{SE} \\ \text { wściec się 'rage.PF' } & \mathrm{SE} \\ \text { zaciekawić 'interest.PF' } & \mathrm{OE} \\ \text { zniechęcić 'discourage.PF' } & \mathrm{OE} \\ \text { rozczarować 'disillusion.PF' } & \mathrm{OE} \\ \text { przeszkodzić 'annoy.PF' } & \mathrm{DE} \\ \text { zaimponować 'impress.PF' } & \mathrm{DE}\end{array}$

Most perfective psych verbs are marked with a prefix, like most other verbs in the perfective aspect in Polish. As observed by Rozwadowska (2003), most if not all psych verbs lack secondary imperfective forms. As the prefixes found in the perfective psych verbs encode temporal notions and specifically, the onset of a state, following Ramchand (2004), they can be analyzed as superlexical. As shown in (14), the Polish inceptive/inchoative prefix $z a$-, also found in the perfective verbs in (12b) and (12l) above, picks the onset of a dynamic activity of playing music, similarly to the Russian prefix $z a$-, which also picks the onset of a dynamic process, as shown in (13) from Ramchand (2004, p. 341). In Ramchand's (2004, p. 351) classification, a superlexical prefix can pick a different definite temporal moment in the event's running time: an onset, which is not a telic point, an arbitrary final moment which does not correspond to a culmination ('a terminal point'), as well as a final moment which is a transition to a result state ('a set terminal point'). Only the latter is a telic moment.

$$
\begin{array}{ll}
\text { Kompjuter } & \text { za-rabotal. } \\
\text { computer.NOM } & \text { INC-worked.PF } \\
\text { 'The computer started working.' }
\end{array}
$$

$\begin{array}{llllll}\text { Orkiestra } & \text { za-grała } i & \text { wszyscy } & \text { ruszyli } & \text { do } & \text { tańca. } \\ \text { band.NOM } & \text { INC-played.PF and } & \text { all } & \text { rushed.PF } & \text { to } & \text { dance.GEN }\end{array}$

'The band started playing and everybody rushed to dance.'

\footnotetext{
${ }^{7}$ Perfective and imperfective are categories of grammatical or viewpoint aspect. The perfective is used in reference to complete, but not necessarily completed situations. Perfective morphology involves singular events. There is no single marker of the perfective aspect in all the Slavic languages, including Polish, but most perfective verbs have a prefix. The imperfective is used in reference to incomplete or not necessarily complete situations. Imperfectivity is marked productively with aspectul suffixes attaching to prefixed perfective stems in verb forms generally referred to as secondary imperfectives, although not all perfective prefixed verbs have secondary imperfective forms, e.g., pisać 'write.IMPF', przepisać 'copy.PF', przepisywać 'copy.IMPF', budować 'build.IMPF', zbudować 'build.PF, *zbudowywać '(intended meaning) build.IMPF'. Imperfective morphology is ambiguous and correlates both with a habitual and a progressive aspectual meaning. Progressive aspect involves singular events and the habitual refers to a plurality of events.
} 


\subsection{The temporal properties of perfective psych predications in Polish: Rozwadowska $(2003,2012)^{8}$}

Based on standard (a)telicity tests, Rozwadowska (2003, 2012) argues that Polish imperfective psych verbs denote (emotional or mental) states while their perfective partners refer to their onsets. In addition, although perfective psych predicates pattern with achievements with respect to several (a)telicity tests, they are not telic, but atelic. By contrast, typical accomplishment verbs in the perfective (e.g., napisać 'write.PF') pass all the standard telicity tests while their imperfective partners pattern with activities under the standard telicity tests. Her conclusions are based on the availability of temporal adverbials illustrated in (15) and (16) and the time-related entailments shown in (17)-(19), which are summarized in (20): ${ }^{9}$

$\begin{array}{llllll}\text { Film } & \text { zainteresowat Marie } & w & \text { godzine } & / & \text { *godzinę. } \\ \text { film.NOM } & \text { interested.PF Mary.ACC } & \text { in } & \text { hour } & / & \text { hour }\end{array}$

'The film started to interest Mary in an hour/for an hour.'

$\begin{array}{llllll}\text { Film } & \text { interesowat } & \text { Marie } & * \text { wodzine } / & \text { godzine. } \\ \text { film.NOM } & \text { interested.IMPF } & \text { Mary.ACC } & \text { in hour } & \text { / hour }\end{array}$

(17) Film zainteresowat Marię $w$ t DOES NOT ENTAIL Film interesowat Marię przed t. 'The film started to interest Mary at $t$.' DOES NOT ENTAIL 'The film interested Mary before $t$ '’

(18) Film interesowat Marię $w$ t. ENTAILS Film zainteresowat Marię przed $\mathrm{t}$. 'The film interested Mary at $t$.' ENTAILS 'The film started to interest Mary before $t$.'

(19) Film zainteresowat Marię $w$ t. ENTAILS Film interesowat Marie po t.

'The film started to interest Mary at $t$. ENTAILS The film interested Mary after $t$.'

(20) a. PERFECTIVE at $t$ DOES NOT ENTAIL IMPERFECTIVE before $t$.

b. IMPERFECTIVE at $t$ ENTAILS PERFECTIVE before $t$.

c. PERFECTIVE at $t$ ENTAILS IMPERFECTIVE after $t$.

\footnotetext{
${ }^{8}$ Imperfective SE psych predicates pass the standard stativity tests in Polish: they are compatible with durative temporal adverbials like (przez) 2 lata '(for) 2 years', they cannot be interpreted progressively in contexts inducing the on-going dynamic reading in the absence of a shifter such as the adverbial coraz bardziej 'more and more', and they receive non-habitual interpretation in the present tense. In addition, incompatibility with temporal event-related adverbials suggests that they are not Davidsonian states. I do not provide a detailed discussion of the temporal properties of imperfective SE verbs for reasons of space limitations and address the reader to Biały (2005), who provides a detailed analysis of both SE and OE psych verbs in Polish. Based on a battery of tests diagnosing the temporal constitution of the eventualities denoted by OE verbs, including availability of temporal (punctually locating, time-span, time-frame) and counting adverbials with OE verbs, their (un)availability in imperative structures, progressive and habitual readings, Biały (2005, p. 76 ) divides Polish OE verbs into stative and non-stative. The stative class includes brzydzić 'nauseate.IMPF', niepokoić 'bother.IMPF', martwić 'worry.IMPF', interesować 'interest.IMPF' and trapić 'plague.IMPF'. The eventive class includes irytować 'irritate.IMPF', straszyć 'scare.IMPF', nudzić 'bore.IMPF', rozbawić 'amuse.PF', and rozczarować 'disappoint.PF'. The stative OE predicates consist of two temporally coexistent events: the causing event and the emotional state (but see Rozwadowska (2012) for a critique). In the non-stative OE psych predicates, the two events are temporally independent.

${ }^{9}$ Rozwadowska (2003, p. 8, also Rozwadowska, 2012, p. 538) illustrates the distribution of time-frame and timespan adverbials in predications with psych verbs with the verb(s) rozumieć 'understand.IMPF' and zrozumieć 'understand.PF'. I provide a verb of emotion here, as the focus is on emotion eventualities. Examples (15)-(19) are modelled on Rozwadowska (2012, p. 539).
} 
Crucially, the temporal entailments of inceptive psych predications are reverse to the entailments that activity and accomplishment predicates generate:

\section{a. IMPERFECTIVE at $t$ DOES NOT ENTAIL PERFECTIVE before $t$. \\ b. PERFECTIVE at $t$ ENTAILS IMPERFECTIVE before $t$.}

In addition, Rozwadowska points out that the adverb prawie 'almost' does not invoke the counterfactual/scalar ambiguity combined with perfective psych predicates and it is impossible with their imperfective partners. This is in contrast to perfective accomplishment predicates, where prawie gives rise to the reading that the eventuality in question did not occur or that it was not completed. The imperfective partner of an accomplishment predicate is not inconsistent with prawie, but the only available reading is the counterfactual one.

Another important property of psych predicates is that they do not provide evidence of a process leading up to the onset of a psych state. ${ }^{10}$ This is illustrated in (22) from Rozwadowska (2012, p. 541):

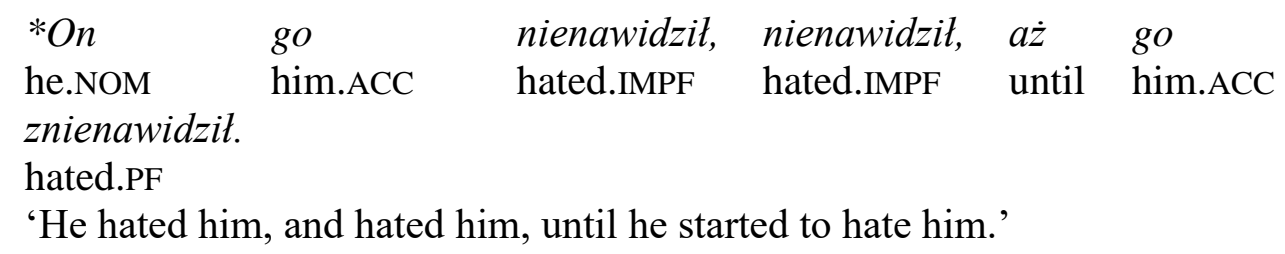

Finally, psych predicates are incompatible with the phasal verb skończyć 'finish.PF', which is consistent with accomplishments, but they can co-occur with the aspectualizer przestac 'stop.PF'. Also activities and states can co-occur with przestać, but not with skończyć: ${ }^{11}$

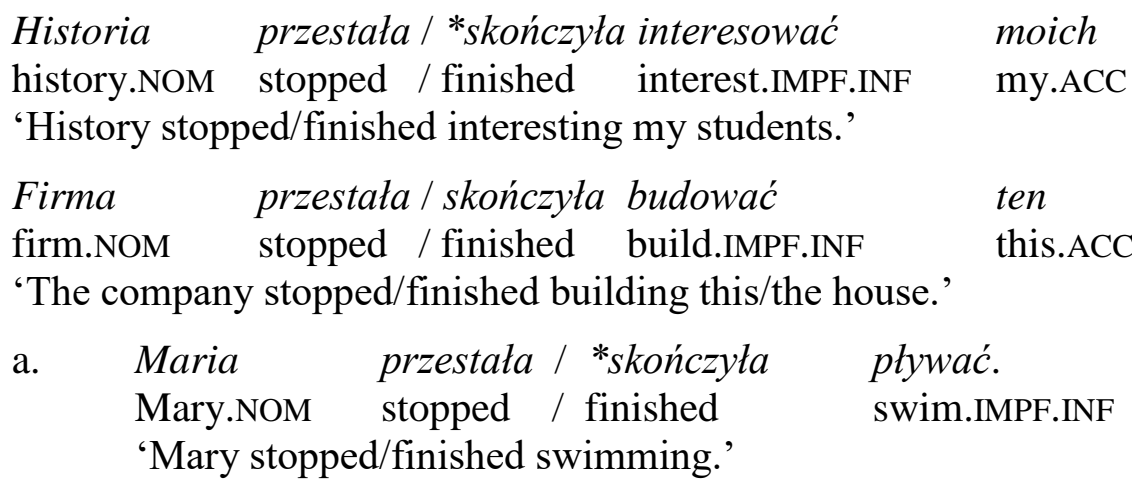
b. Janek przestal / *skończyt chorować.
John.NOM stopped / finished be_ill.IMPF.INF
'John stopped/finished being ill.'

Based on the evidence presented above, Rozwadowska (2003, 2012) concludes that perfective psych verbs are initiation predicates denoting a durationless onset of a state, i.e., a single temporal moment. They can either be punctual and pick just the onset, or they denote the onset and some temporal span of the emotional state lexicalized by the base verb. This ambiguity is restricted to OE verbs. SE psych verbs always have a state in their denotation. In suggesting that the ontology of the eventualities in natural language includes durationless

\footnotetext{
${ }^{10}$ The strength of this argument depends on whether the verb nienawidzic 'hate' has a process reading and whether its denotation can be coerced to a dynamic process, i.e., an activity.

${ }^{11}$ Notice that only imperfective verbs can co-occur with the phasal verbs przestać 'stop' and skończyć 'finish'.
} 
events, she falls back on Piñón (1997), who proposes to analyze punctual events as the boundaries of 'thick events' or happenings in their vicinity. Predicates like win the game pick the right boundary of the playing-the-game event. Predicates like begin to run pick the left/initial boundary of the thick event/happening of running in their vicinity. What is crucial in Piñón's (1997) approach is that a boundary happening is an eventuality of some sort and the happening it bounds cannot be immediately preceded by an eventuality of exactly the same sort. Otherwise, the happenings could always be summed up into a single eventuality. In this scenario, the unavailability of (22) follows straightforwardly, as a hating eventuality immediately precedes an onset of an eventuality which is also a hating eventuality, i.e., a state (see fn. 10). Also Marín and McNally (2011) advocate the left boundary approach to the event structure of Spanish reflexive psych predicates, which they also divide into two kinds: a punctual eventuality picking only an onset of an associated state, and a left-boundary state, i.e., a state including also its onset. ${ }^{12}$ If all punctual Spanish reflexive psych predicates refer to an onset of an associated state without referring to the change that produces that state, inchoativity is logically distinct from change of state. Marín and McNally (2011, p. 471) explain the difference between predicates denoting a change of state and those that do not as follows:

Imagine that a predicate is lexically specified to refer to the true initial interval of a state, but not to any interval prior to the onset of that state. If the predicate entails reference to this initial interval, it will have to be the case that prior to that interval, the state did not hold. From this fact it will be possible to infer that a change has taken place immediately prior to the onset of the state being referred to. Thus, though such a predicate would qualify as inchoative in the same sense as BECOME, it would not qualify as a change of state predicate in the same sense.

Importantly, in the analysis that Marín and McNally (2011, pp. 491-492) offer, an inchoative predicate is "any predicate which describes an eventuality which necessarily is or includes the beginning of some happening." Inchoative predicates are atelic, because unlike telic predicates, which crucially include the right boundary of a happening which is a telic (finishing) endpoint, atelic predicates do not describe eventualities with right boundaries. Not being events of change of state, inchoative eventualities are also non-dynamic, contradicting the common assumption that punctuality correlates with dynamicity.

The insights offered into the logical differences between events of change of state and inception or inchoative eventualities offered by Piñón (1997), Rozwadowska (2003, 2012), and Marín and McNally (2011) are an important contribution to the typology of eventualities described with verbal predicates in natural language. In the next section, I consider the relevance of modifying perfective psych predicates with the comparative degree quantifier jeszcze bardziej 'even more', illustrated in (7) and repeated below for convenience in (26), for the analysis of the event structure of perfective psych verbs. The example illustrating the unmodified psych predicate is repeated in (27). The main question is whether the distribution of a comparative adverb jeszcze bardziej can tease apart the analysis on which perfective psych predicates make reference to a single temporal moment or to a minimal interval with two time instants, the last instant at which the emotional state does not hold and the initial instant at which it holds.

\footnotetext{
${ }^{12}$ I refer the reader to Marín and McNally's (2011) article for the discussion of the Spanish data and the concept of boundary events as well as a formal semantic analysis.
} 


$\begin{array}{lllll}5 & \text { rzeczy, } & z a \quad \text { które twój } & \text { facet } & \text { cię } \\ 5 & \text { things.GEN } & \text { for which.PL.ACC your.NOM } & \text { man.NOM } & \text { you.ACC } \\ \text { jeszcze bardziej } & \text { po-kocha! } & \\ \text { even more } & \text { INC-love.PF.3SG.PRES } & \\ \text { '5 things for which your man will start to love you even more!' }\end{array}$

$\begin{array}{llllll}6 & \text { powodów, } & \text { dla których po-kochasz } & \text { kapustę } \\ 6 & \text { reasons.GEN for which.PL.GEN INC-love.PF.2SG.PRES cabbage.ACC }\end{array}$

' 6 reasons for which you will start to love cabbage'

\section{$3 \quad$ Modification of perfective psych VPs by degree quantifiers}

Psych verbs modified by adverbs like a lot, a bit, slightly, etc., as well as by comparative adverbs like more and less, have an intensity reading that is not available with other verbs in superficially similar structures. In contrast to (28b), which has an intensity reading, the comparative in (29a) compares the frequency of events of hitting rather than their intensity. To generate an intensity reading, an overt degreeable predicate must combine with a verb like hit, as shown in (29b). Such an addition is not necessary with stative scalar verbs like love, as observed by Gawron (2006):

(28) a. John loves Mary a lot/a bit/slightly.

b. John loves Mary more than Sue.

(29) a. John hit Mary more than Sue.

b. John hit Mary harder than Sue.

In the influential approach to the semantics of gradable predicates and comparatives in Kennedy and McNally (2005), Kennedy (2007) and Kennedy and Levin (2008), degree morphology introduces a degree on a scale lexicalized by an adjective or an adjectival root of a scalar verb that an entity must possess at a particular time for the degree construction, e.g., wider and widen, to be predicated of that entity. In comparatives, the comparative morphology introduces a derived difference measure function with a scale whose minimal element corresponds to the degree introduced by the than-clause, called the comparative standard. Informally, the degree which a derived difference function returns for the entities in its domain is the difference between the degree that the entity has on the scale at the particular time and the comparative standard, an arbitrary non-zero degree. For example, in the comparative structure in (28b), the degree of John's love of Mary exceeds the comparative standard at the time $t$ at which it is true that John loves Mary and that John loves Sue. ${ }^{13}$ Applied in (26), the difference function returns the degree to which my man's love of me at the reference time for the event described with the perfective predicate po-kochac 'INClove.PF' exceeds the degree introduced by the comparative standard, which is the implicit and inferred or reconstructed degree to which my man loves me at utterance time. The contribution of jeszcze 'even' is to add a requirement that the degree introduced by the comparative standard is high.

\footnotetext{
${ }^{13}$ The choice of Kennedy and McNally's (2005) degree-based approach to comparatives for the purposes of this paper is motivated by a more transparent analysis of the contribution of the complement than-clause in comparative structures in that model compared with the degree-less approach of Klein (1980), but either framework should be able to capture the phenomenon discussed here. Notice that a difference measure function as conceived of by Kennedy and Levin (2008, p. 172) is a relation between objects, degrees and times.
} 
Formalization issues aside, the question that arises in the context of structures like (26) in Polish is what kind or kinds of eventualities po-kochać 'INC-love.PF' denotes in contrast to its imperfective partner kochać 'love.IMPF', and in particular, whether a perfective psych verb lexicalizes BECOME in its event structure.

If the inceptive prefix po- asserts a temporal moment at the onset of a state lexicalized in the base verb, as argued by Ramchand (2004), a perfective predicate like po-kochać 'INC-love.PF' cannot lexicalize BECOME on standard assumptions, as change requires some duration to take place (see Piñón, 1997). If pokochać in (26) lexicalizes a change of state modelled with BECOME, it must be true of a minimal interval with two adjacent moments, $t_{l}$, the final moment in which the Experiencer is not in a state of love and $t_{2}$, the initial instant in which the Experiencer is in the state of love in a situation described with the sentence in (26). However, the most natural interpretation that (26) has is that the perfective psych predicate asserts a single moment which is the beginning of the state the Experiencer is in at the reference time for the perfective event, but the Experiencer is in that state also at a time instant or instants (immediately) prior to the moment picked by the perfective operator. The contexts in (30)-(32) below are naturally-occurring examples demonstrating that the Experiencer is in the emotional state described by the perfective psych verb at the time of event described by the perfective predicate modified by jeszcze bardziej 'even more' and also that this state is not entailed to cease or to have ceased prior to the event referred to with the perfective verb. The contexts involving jeszcze bardziej 'even more' illustrated in (30)-(32) involve different types of psych verbs. The psych verb in (30) is a non-reflexive SE verb. In (31), the SE verb is reflexive. Reflexive verbs are marked with się in Polish, similarly to many other languages (see Alexiadou and Iordăchioaia, 2014). The verb in (32) is an OE verb. As shown, the intervals including the instants that the difference measure function incorporated in the comparative degree quantifier relates to objects and degrees may overlap temporally with the instant picked by the inceptive prefix and/or the perfective operator.

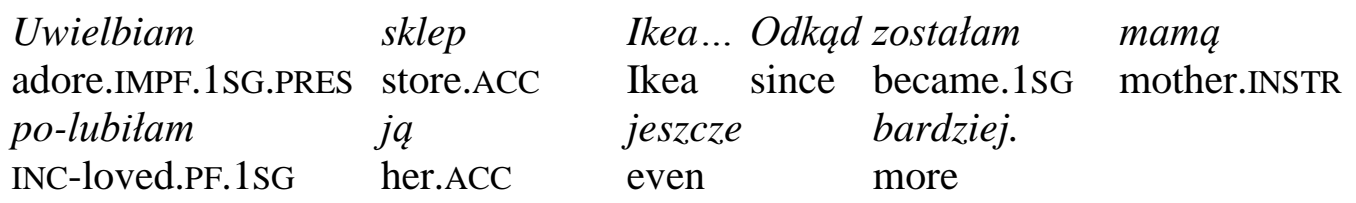

'I adore the Ikea shop... Since I became a mother, I have started to like it even more.' http://www.hityikity.pl/jak-zaskoczyla-mnie-ikea-reklamacje/

$\begin{array}{llllll}\text { Gdzie się } & \text { podziewasz? - } & \text { od } & \text { wejścia } & \text { dat } & \text { się } \\ \text { where RF } & \text { hang.IMPF.2SG.PRES from } & \text { entrance.GEN } & \text { let.PF.3SG.PAST } & \text { RF } \\ \text { styszé } & \text { zdenerwowany głos } & \text { ojca } & \text { Wiktorii } & \\ \text { hear.IMPF.INF upset.SG.NOM voice.NOM } & \text { father.GEN } & \text { Victoria.GEN } & \end{array}$

'Where are you hiding? - The angry voice of Victoria's father was heard already at the door.'

\begin{tabular}{|c|c|c|c|c|}
\hline $\begin{array}{l}\text { Co } \\
\text { what }\end{array}$ & $\begin{array}{l}\text { robisz? - } \\
\text { do.IMPF.2SG.PRES }\end{array}$ & $\begin{array}{l}\text { jeszcze } \\
\text { even }\end{array}$ & $\begin{array}{l}\text { ej sie } \\
\text { RF }\end{array}$ & $\begin{array}{l}\text {-denerwowat, } \\
\text { NC-upset.PF.3SG.PAST }\end{array}$ \\
\hline & $k l e ̨ c z a c a$ & córkę, & szorujaca & a posadzke \\
\hline when & $\begin{array}{l}\text { saw.PF.3SG.M kneeling.ACC } \\
\text { kościele. }\end{array}$ & C daughter.ACC & scrubbing & floor.ACC \\
\hline
\end{tabular}

'What are you doing? - he started to feel even more irritated when he noticed his daughter kneeling down scrubbing the church floor.'

http://brygada.malyrycerzyk.pl/opowiesci/index11.php 


$\begin{array}{lllll}\text { Nie znam } & \text { chyba } & \text { osoby, która } & \text { nie } \\ \text { not know.IMPF.1SG.PRES } & \text { probably person.GEN who.GEN } & \text { not } \\ \text { narzekałaby } & \text { na to, jak działa } & \\ \text { complained.IMPF.3SG.COND } & \text { on it.ACC how work.IMPF.3SG.PRES } & \end{array}$

\section{komunikator Facebooka.}

communicator.NOM Facebook.GEN

'I probably do not know a person who would not complain how Facebook's communicator works.'

$\begin{array}{lllllll}\text { Tymczasem Mark } & \text { Zuckerberg } & \text { zdaje } & \text { się robić } & \text { wszystko, } \\ \text { still } & \text { Mark } & \text { Zuckerberg } & \text { seem.IMPF.3SG.PRES RF } & \text { do.IMPF.INF everything } \\ \text { aby jeszcze } & \text { bardziej } & \text { zniechęcić } & \text { nas } & \text { do Messengera } \\ \text { to } & \text { even } & \text { more } & \text { discourage.PF.INF us.ACC } & \text { to } & \text { Messenger.GEN }\end{array}$

'Still Mark Zukerberg seems to be doing everything to discourage us even more from the Messenger.'

http://www.appki.com.pl/artykuly/facebook-moneypenny/

As the larger linguistic contexts in which the perfective psych predicates occur make clear, pragmatic inferencing favors the interpretations on which the Experiencer of the eventualities described with the perfective psych predicates shown above is in the given emotional state immediately prior to the occurrence of the perfective event. For example, it is highly unlikely that in the situation described in (31), Victoria's father is upset entering the church as can be inferred from his upset voice, calms down before he notices his daughter, and on seeing her is upset again. Rather, what the perfective psych predicate modified by the degree quantifier jeszcze bardziej 'even more' refers to in (31) is an increase in the extent of Victoria's father's upset feeling that is measured at a single moment in time relative to an arbitrary degree, pragmatically interpreted in context as the degree of his upset feeling at the moment he enters the church. The opening sentence in (30) refers to the speaker's disposition and to the extent that mental attitudes are time-persistent, i.e., that they hold of all the temporal slices of the Experiencer, the speaker can be expected to have a loving attitude with respect to the Ikea store in the temporal stage referred to with the perfective verb in (30) as well as in all other temporal stages. A change of state interpretation, on which immediately prior to the event described with the perfective predicate in (30), the speaker does not like Ikea, is at best counterintuitive. Also the context illustrated in (32) makes clear that Facebook users are in general disaffected with Facebook's Messenger communicator and that their emotional attitude holds immediately prior to the event described with the OE perfective predicate zniechęcić 'discourage.PF' modified with jeszcze bardziej 'even more'. What the comparative degree quantifier contributes is a degree of the intensity of the emotional state at the onset of the state, which is some vague degree exceeding the degree of the intensity of the same state at a distinct interval and a distinct temporal stage of the referent of the Experiencer argument. However, the events referred to with (26) and with the sentences with perfective psych verbs in (30)-(32) are not events of change of degree of intensity of the Experiencer's state over the time of the event denoted by the perfective predicate and the time instant corresponding to the onset and the time instant in the comparative standard are not the final and the initial moments of a single event of change of degree on the scale of intensity, respectively. If perfective psych predicates modified by a comparative degree quantifier denoted events of change extended over the interval including the two instants involved in comparison, we could expect that interval to be accessed by a modifier like coraz bardziej 'more and more', but the ungrammaticality of (33) rules this possibility out. As (34) demonstrates, the imperfective predicate kochać 'love.IMPF' is consistent with the gradual degree adverb coraz bardziej 'more and more', providing evidence that the state it denotes can be graded with respect to 
intensity over an interval (see Piñón, 2000). Nevertheless, coraz bardziej 'more and more' is not compatible with a perfective psych predicate: ${ }^{14}$

$\begin{array}{llll}* \text { Po-kochatam } & \text { cię } & \text { coraz } & \text { bardziej. } \\ \text { INC-loved.PF.1SG } & \text { you.ACC } & \text { each_time } & \text { more }\end{array}$

'I started to love you more and more'.

\begin{tabular}{|c|c|c|c|c|}
\hline $\begin{array}{l}Z \quad k a \dot{z} d y m \\
\text { with each } \\
\text { bardziej. } \\
\text { more }\end{array}$ & $\begin{array}{l}\text { dniem } \\
\text { day }\end{array}$ & $\begin{array}{l}\text { kocham } \\
\text { love.IMPF.1SG.PRES }\end{array}$ & $\begin{array}{l}\text { cię } \\
\text { you.ACC }\end{array}$ & $\begin{array}{l}\text { coraz } \\
\text { each_time }\end{array}$ \\
\hline
\end{tabular}

Thus, the degree returned by the difference function contributed by degree morphology in a comparative construction is the degree of intensity to which the state holds at the moment of its onset, which is greater than at a distinct time instant or interval. Modulo the relation to a distinct instant or interval in the comparative standard, the function of a comparative degree quantifier is similar to the function that other degree quantifiers perform with respect to the denotation of the VP that they modify. For example, in (35), the adverb bardzo 'a lot' specifies that the degree of the intensity of the farmer's love of his animals is a high degree at the reference time picked by the perfective operator. In (36), the degree of discouragement is a low degree:

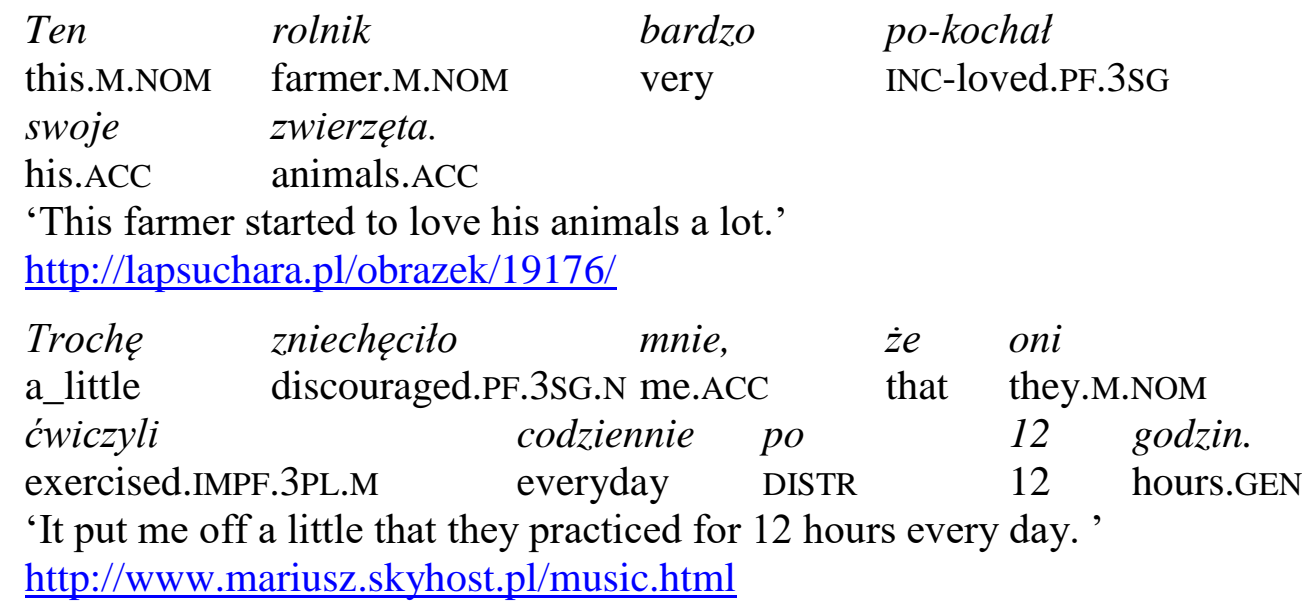

In contrast to a perfective predicate modified by a degree quantifier, an unmodified perfective psych predicate triggers the entailment that no amount of the eventuality it refers to holds immediately prior to it. For example, (27) asserts that you will start to love cabbage, and it entails that you do not love cabbage now. I suggest that this difference reflects the requirement built into the theory of boundary events by Piñón (1997). If a happening is to be a boundary of a thick event in its vicinity, the thick eventuality cannot be preceded by an

\footnotetext{
${ }^{14}$ The adverb of gradual change of degree coraz bardziej 'more and more' is inconsistent with perfectivity in Polish, but perfective psych verbs also cannot be modified by the rate adverb powoli 'slowly', which can modify a perfective verb of gradual change/degree achievement; cf. (i) vs. (ii):
(i) *Po-kochat mnie powoli. INC-loved.PF.3SG.M me.ACC slowly. '(intended) He slowly started to love me.'

$$
\begin{array}{lll}
\text { Chudnij / s-chudnij } & \text { powoli! } \\
\text { be_thin.IMPF.IMP / TERM-be_thin.PF.IMP } & \text { slowly }
\end{array}
$$$$
\text { 'Lose weight slowly!' }
$$ 
identical eventuality, as the two eventualities could be summed up into a 'bigger' eventuality. That the left boundary of the state in (27) cannot be preceded by the same state follows from the logic of beginnings, specifically, from the impossibility of interpreting an event as an onset of a state if the same state precedes that state. Events of starting to love someone in the denotation of the sentence in (26) do not entail absence of the love state in their vicinity, unlike in (27). The predicate love and the predicate love more do not have the same truth conditions and as they cannot be summed up into a 'bigger' eventuality, the eventuality denoted by predicate love can in fact occur in the vicinity of love some more in (26), in contrast to (27).

To wrap up, the distribution of the comparative degree quantifier jeszcze bardziej 'even more' provides evidence that the predicate it modifies does not denote a change of state. The eventuality described in the lexical structure of the verb or the root denotes an onset or beginning of an emotional state that provides a gradable dimension along which it can be 'measured', i.e., intensity. A degree quantifier combined with a VP built on a psych verb does not change its event structure, but modifies it by specifying the degree corresponding to the difference on the intensity scale with respect to the comparative standard, similarly to a degree modifier such as bardzo 'very' and troche 'a bit', as illustrated in (35) and (36).

To the extent that a vague comparative degree quantifier like jeszcze bardziej 'even more' can combine with a perfective psych verb, it provides evidence that the scale it quantifies over lacks the maximum degree. That psych verbs have lower closed scales is further suggested by their comparative entailment pattern, which is analogous to the entailment generated by an adjective with a scalar minimum, but not with a scalar maximum in comparative statements. ${ }^{15}$ As shown in (37), $x$ is more than $y$ entails that $x$ is $P$ in lower closed adjectives such as open, that $y$ is not $P$ in adjectives with a scalar maximum such as closed, and neither in relative adjectives (see Doetjes, 2008; Katz, 2008; Toledo and Sassoon, 2011). That psych predicates pattern with lower closed adjectives like open, and not with upper closed adjectives like closed or relative adjectives like long is shown in (38) and (39). Crucially, (38a) entails (38b) and (39a) entails (39b): ${ }^{16}$

(37) a. The door is more open than the window. ENTAILS The window is open.

b. $\quad$ The door is more closed than the window. ENTAILS The window is not closed.

c. $\quad \operatorname{Rod} A$ is longer than $\operatorname{Rod} B$. DOES NOT ENTAIL Rod A is long / Rod B is not long.

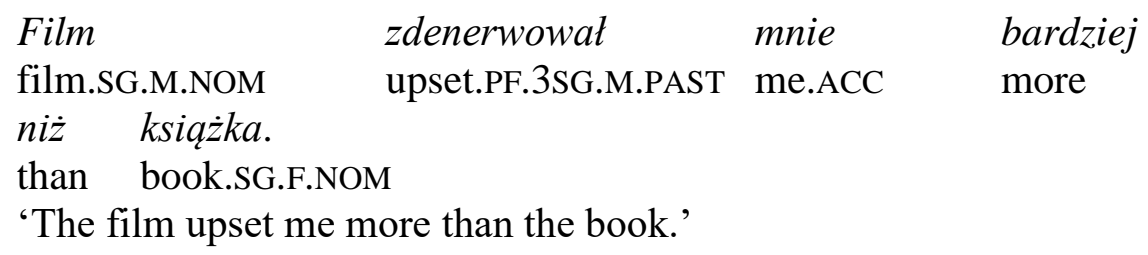

\footnotetext{
${ }^{15}$ Whether all Polish psych verbs have the entailment patterns demonstrated in (38) and (39) in both the imperfective and the perfective aspect needs to be verified against a larger body of data, but this task is beyond the scope of this paper.

${ }^{16}$ What this means is that in unmodified contexts, when an emotional state holds of the Experiencer argument, the degree of its intensity is a minimal degree that is necessary for the verbal property to be manifested in the event. In modified contexts, as in the context of troche 'a bit', bardzo 'a lot or jeszcze bardziej 'even more', this degree is raised to some degree above the scalar minimum, to some high degree or to some degree higher than the arbitrary degree introduced by the comparative standard respectively. I assume here that the scalar minimum in tandem with the semantics of beginnings imposes an increasing relation on the degrees on the intensity scale.
} 


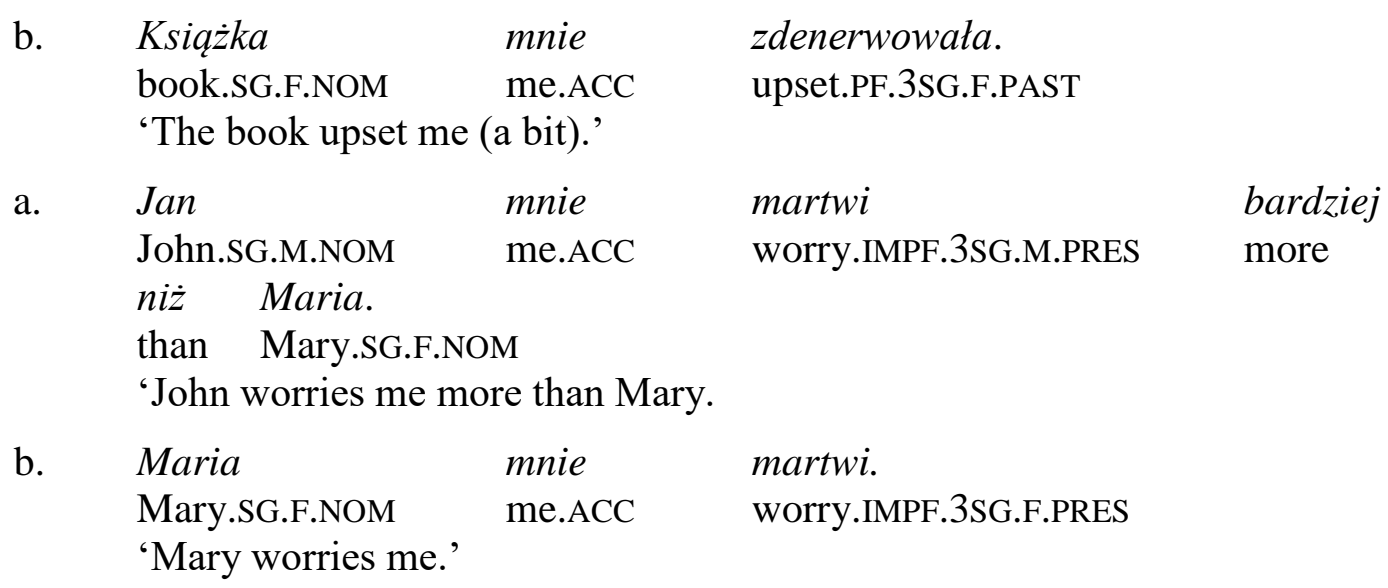

\section{Conclusion}

Predicates like fall in love and frighten have often been analyzed as events of change of state which takes place over a two-point interval consisting of the instant in which $\neg \alpha$ is true adjacent to the instant at which $\alpha$ is true. Punctual events of change of state have traditionally also been treated as dynamic and telic. This traditional wisdom has recently been challenged by Rozwadowska $(2003,2012)$ in reference to Polish psych SE and OE verbs and by Marín and McNally (2011) in reference to Spanish reflexive SE verbs, who suggest that psych verbs do not denote a change of state. Rather, they either make reference to an onset of an associated state alone, or to both to an onset and a state. To their arguments, I have added here additional data from degree quantification in the domain of psych predications. The distribution of the degree quantifier jeszcze bardziej 'even more' in sentences with psych verbs in the perfective aspect shows that a perfective psych predication does not describe a transition from the Experiencer not being in the emotional state lexicalized in the verb/root to being in that state in Polish. I have proposed here that in the context of a comparative degree quantifier, a perfective predicate denotes an onset of a state and the comparative degree modifier contributes the degree of intensity of the state at the time instant which corresponds to the onset. While a degree quantifier attached in the syntax contributes additional information about VP denotation, it does not affect the event structure of a perfective predicate. Contexts involving comparative degree quantifiers thus provide additional evidence that verbal predicates may refer to an onset of a state they are associated with without referring to a change that produces that state and thus that punctuality need not correlate with dynamicity in natural language, as has been argued on other grounds with respect to Polish by Rozwadowska (2003, 2012) and in reference to Spanish by Marín and McNally (2011). The availability of degreeable perfective verbs in verbal comparatives provides additional evidence that the scales associated with the states described by psych verbs are upper open and that psych predications are atelic rather than telic. Being atelic, Polish perfective psych verbs do not provide counterevidence to the generalization advanced in Wellwood, Hacquard, and Pancheva (2012) based on an investigation into the temporal or spatial extents of events, that the only perfective predicates licensed in verbal comparatives in natural language are atelic predicates. 


\section{References}

Alexiadou, A. and Iordăchioaia, G. (2014). The psych causative alternation. Lingua, 148, 5379.

Arad, M. (1999). What counts as a class? The case of psych verbs. MIT Working Papers in Linguistics, 35, 1-23.

Biały, A. (2005). Polish psychological verbs at the lexicon-syntax interface in cross-linguistic perspective. Frankfurt am Main: Peter Lang.

Croft, W. (2012). Verbs: Aspect and argument structure. Oxford: Oxford University Press.

Doetjes, J. (2008). Adjectives and degree modification. In L. McNally and C. Kennedy (Eds.), Adjectives and adverbs: Syntax, semantics, and discourse (pp. 123-155). Oxford: Oxford University Press.

Dowty, D. (1991). Thematic proto-roles and argument selection. Language, 67, 547-619.

Filip, H. (1996). Psychological verbs and the syntax-semantics interface. In A. Goldberg (Ed.), Conceptual structure, discourse and language (pp. 131-147). Stanford, CA: CSLI.

Gawron, M. (2006). Paths and scalar change. (Manuscript). San Diego State University. http://www-rohan.sdsu.edu/ gawron/new_scales_paper.pdf

Grimshaw, J. (1990). Argument structure. Cambridge, MA: MIT Press.

Jackendoff, R. (2009). Language, consciousness, culture. Essays on mental structure. Cambridge, MA: MIT Press.

Katz, J. J. (2008). Manner modification of state verbs. In L. McNally and C. Kennedy (Eds.), Adjectives and adverbs: Syntax, semantics, and discourse (pp. 220-248). Oxford: Oxford University Press.

Kennedy, C. (2007). Vagueness and grammar: The semantics of relative and absolute gradable adjectives. Linguistics and Philosophy, 30, 1-45.

Kennedy, C. and Levin, B. (2008). Measure of change: The adjectival core of degree achievements. In L. McNally and C. Kennedy (Eds.), Adjectives and adverbs: Syntax, semantics, and discourse (pp. 156-182). Oxford: Oxford University Press.

Kennedy, C. and McNally, L. (2005). Scale structure and the semantics of gradable predicates. Language, 81, 345-381.

Klein, E. (1980). A semantics for positive and comparative adjectives. Linguistics and Philosophy, 4, 1-46.

Landau, I. (2010). The Locative syntax of experiencers. Cambridge, MA: MIT Press.

Levin, B. and Rappaport Hovav, M. (2005). Argument realization. Cambridge: Cambridge University Press.

Levin, B. and Grafmiller, J. (2013). Do you always fear what frightens you? In T. H. King and V. de Paiva (Eds.), From quirky case to representing space: Papers in honor of Annie Zaenen (pp. 21-32). Stanford, CA: CSLI Online Publications.

Marín, R. and McNally, L. (2011). Inchoativity, change of state and telicity. Natural Language and Linguistic Theory, 29, 467-502.

Pesetsky, D. (1995). Zero syntax: Experiencers and cascades. Cambridge, MA: MIT Press. 
Piñón, C. (1997). Achievements in an event semantics. In A. Lawson and E. Cho (Eds.), Proceedings of SALT VII (pp. 273-296). Cornell University, Ithaca, NY: CLC Publications.

Piñón, C. (2000). Happening gradually. In L. J. Conathan, J. Good, D. Kavitskaya, A. B. Wulf, and A. C. L. Yu (Eds.), Proceedings of twenty-sixth annual meeting of the Berkeley Linguistic Society (pp. 445-456). Berkeley, CA: Berkeley Linguistic Society.

Pustejovsky, J. (1991). The syntax of event structure. Cognition, 41, 47-81.

Ramchand, G. (2004). Time and the event: The semantics of Russian prefixes. Nordlyd, 32, 323-361.

Rothmayr, A. (2009). The structure of stative verbs. Amsterdam: Benjamins.

Rothstein, S. (2008). Two puzzles for a theory of lexical aspect: semelfactives and degree chievements. In J. Dölling, T. Heyde-Zybatow, and M. Schäfer (Eds.), Event structure in linguistic form and interpretation (pp. 175-198). Berlin: Mouton-De Gruyter.

Rozwadowska, B. (2003). Initial boundary and telicity in the semantics of perfectivity. In P. Kosta, J. Błaszczak, J. Frasek, L. Geist, and M. Żygis (Eds.), Investigations into formal Slavic linguistics (pp. 859-872). Frankfurt am Main: Peter Lang.

Rozwadowska, B. (2012). On the onset of psych eventualities. In E. Cyran, H. Kardela, and B. Szymanek (Eds.), Sound structure and sense (pp. 533-554). Lublin: Wydawnictwo KUL.

Toledo, A. and Sassoon, G. (2011). Absolute vs. relative adjectives - variance within vs. between individuals. In N. Ashton, A. Chereches, and D. Lutz (Eds.), Proceedings of Semantics and Linguistic Theory 21 (pp. 135-154). Linguistic Society of America, Conference Proceedings. doi: http://dx.doi.org/10.3765/salt.v21i0.2587

Vendler, Z. (1967). Linguistics in philosophy. Ithaca, NY: Cornell University Press.

Van Voorst, J. (1992). The aspectual semantics of psychological verbs. Linguistics and Philosophy, 15, 65-92.

Wellwood, A., Hacquard, V., and Pancheva, R. (2012). Measuring and comparing individuals and events. Journal of Semantics, 29, 207-228.

Ewa Willim

Jagiellonian University

Institute of English Studies

Al. Mickiewicza 9, 31-120 Kraków

e-mail: ewa.willim@uj.edu.pl 